Jurnal Ilmiah Ibnu Sina, 5(2), Oktober 2020, 416-425

p-ISSN: 2502-647X; e-ISSN: 2503-1902

\title{
KARAKTERISASI PARAMETER SPESIFIK DAN PARAMETER NON SPESIFIK AKAR KUNING (Fibraurea tinctoria)
}

\author{
Supomo$^{1}$, Hayatus Sa`adah ${ }^{1}$, Eka Siswanto Syamsul ${ }^{1}$, Kintoko², Hardi Astuti \\ Witasari $^{2}$, \\ ${ }^{1}$ Sekolah Tinggi Ilmu Kesehatan Samarinda \\ ${ }^{2}$ Fakultas Farmasi Universitas Ahmad Dahlan, Yogyakarta
}

Email $^{1}$ : fahmipomo@gmail.com

Artikel diterima: 02 Juli 2020; Disetujui: 24 Agustus 2020

DOI: https://doi.org/10.36387/jiis.v5i2.592

\begin{abstract}
ABSTRAK
Salah satu senyawa metabolit sekunder dari akar kuning (Fibraurea tinctoria) yang potensial dikembangkan sebagai obat adalah berberine. Senyawa golongan alkaloid ini dilaporkan memiliki aktivitas antimikroba, antidiare, penghambat infeksi parasit usus, antihipertensi, antitumor, antiinflamasi, hepatoprotektor, antimalaria dan antikanker. Pada pengembahan bahan alam sebagai obat perlu dilakukan standarisasi simplisia dan ekstrak. Tujuan penelitian untuk mengetahui karakterisasi parameter spesifik dan parameter non spesifik tumbuhan akar kuning. Penelitian adalah penelitian eksperimental. Objek penelitian yang digunakan akar kuning yang diperoleh dari Kawasan Hutan Dengan Tujuan Khusus (KDKT) Samboja, kabupaten Kutai Kartanegara, Kalimantan Timur. Simplisia diekstraksi menggunakan metode maserasi dengan pelarut etanol 70\%. Hasil ekstraksi dilakukan karakterisasi meliputi: makroskopik, mikroskopik, kadar air, kadar sari larut air, kadar sari larut etanol, kadar abu, dan kadar abu tidak larut asam selanjutnya dilakukan skrining fitokimia. Data dianalisis secara deskriptif. Hasil karakterisasi serbuk simplisia akar kuning secara makroskopik, merupakan Liana dengan panjang mencapai 10-20 m, dengan batang bulat, kulit batang coklat keabu-abuan, kasar, diameter antara 2-7 cm dan warna serbuk kuning cerah. Mikroskopik serbuk simplisia ditemukan fragmen sel batu dan fragmen trakea. Karakterisasi serbuk simplisia, kadar air 7,3\%, kadar sari larut etanol 6,69\%, kadar sari larut air $8,05 \%$, kadar abu 8,17\%, kadar abu tidak larut asam 0,47\%. Hasil identifikasi golongan senyawa kimia, positif mengandung senyawa kimia berupa alkaloid, flavonoid dan saponin.
\end{abstract}

Kata kunci: Karakterisasi, parameter spesifik, parameter non spesifik, (Fibraurea tinctoria)

ABSTRACT

One of the secondary metabolites from yellow root (Fibraurea tinctoria) that has the potential to be developed as medicine is berberine. Alkaloid class compounds are reported to have antimicrobial, anti-diarrheal, intestinal parasite infection inhibitors, antihypertensives, anti-tumor, anti-inflammatory, 
Jurnal Ilmiah Ibnu Sina, 5(2), Oktober 2020, 416-425

p-ISSN: 2502-647X; e-ISSN: 2503-1902

hepatoprotective, antimalarial and anticancer properties. In the development of natural ingredients as medicine, it is necessary to standardize simplicia and extracts The research objective was to determine the characterization of specific and non-specific parameters of yellow root plants. This research is an experimental research. The object of research used yellow roots obtained from KDKT Samboja, Kutai Kartanegara district, East Kalimantan Province. Samples were made of simplicia which were extracted using the maceration method with $70 \%$ ethanol solvent. The results of the extraction were carried out by characterization including: macroscopic, microscopic, water content, water-soluble extract, ethanol-soluble extract, ash content, and acidinsoluble ash, then phytochemical screening was carried out. Data were analyzed using descriptive methods. The results of macroscopic characterization of yellow root simplicia powder were Liana with a length of 10-20 m, with round stems, bark grayish brown, coarse, 2-7 cm in diameter and bright yellow powder color. The simplicia powder microscopy found stone cell fragments and tracheal fragments. Characterization of simplicia powder, water content of $67.3 \%$, ethanol soluble extract content of $6.69 \%$, water soluble extract content of $8.05 \%$, ash content of $7.37 \%$, acid insoluble ash content of $0.37 \%$. The results of the identification of the chemical compound group were positive for containing chemical compounds in the form of alkaloids, flavonoids and saponins.

Keywords: Characterization, specific parameters, non-specific parameters (Fibraurea tinctoria)

\section{PENDAHULUAN}

Salah satu senyawa metabolit sekunder dari akar kuning yang potensial sebagai obat adalah berberine. Senyawa golongan alkaloid ini dilaporkan memiliki aktivitas anti mikroba, antidiare, penghambat infeksi parasit usus, anti hipertensi, anti tumor, anti inflamasi, hepatoprotektor, anti malaria dan anti kanker (Wongbutdee, 2009).

Data penelitian awal tentang karakterisasi serbuk simplisia maupun ekstrak simplisia belum pernah dilakukan. Karakterisasi berguna untuk mengetahui mutu dari suatu bahan simplisia, salah satu cara untuk mengendalikan mutu simplisia adalah dengan melakukan standardisasi atau karakterisasi simplisia. Karakterisasi simplisia adalah proses yang dilakukan untuk menjamin bahwa simplisia yang akan digunakan sebagai bahan baku obat harus memenuhi persyaratan yang tercantum dalam Materia Medika Indonesia. Berdasarkan pada uraian tersebut maka dilakukan penelitian tentang karakterisasi parameter spesifik dan non spesifik akar kuning. 


\section{METODE PENELITIAN}

\section{Bahan dan Alat}

Bahan yang digunakan dalam penelitian adalah kloralhidrat, amil alkohol, air suling, asam asetat anhidrat, asam sulfat pekat, asam klorida $2 \mathrm{~N}$, asam klorida pekat, besi (III) klorida 1\%, etanol 70\%, pereaksi bouchardat, pereaksi dragendrof, pereaksi mayer, serbuk magnesium, n-heksan, kloroform $P$, dan serbuk simplisia akar kuning.

Alat yang digunakan dalam penelitian adalah alat-alat gelas, gunting, oven kamera, kertas label, kertas saring, lampu spiritus, neraca analitik (matrix), penangas air, penjepit, wadah penyimpanan, maserator, desikator, tanur (carbolite), krus platina, mikroskop, ayakan mesh 60 .

\section{Determinasi Tumbuhan}

Determinasi tumbuhan dilakukan di Herbarium Wanariset Balai Penelitian dan Pengembangan Teknologi Konservasi Sumber Daya Alam (BKSDA) Samboja Kutai Kabupaten Kartanegara, Kalimantan Timur.

\section{Pembuatan Simplisia}

Akar kuning yang telah disortasi basah, dicuci, dikeringkan, lalu dirajang dan dikeringkan dengan cara diangin-anginkan di udara yang terlindungi oleh sinar matahari langsung. Simplisia yang telah kering dibuat serbuk.

\section{Pembuatan Ekstrak}

Simplisia dimaserasi dengan pelarut alkohol $70 \%$ dengan perbandingan 1: 10 selama 24 jam dilakukan remaserasi sebanyak $2 x$, kemudian disaring untuk mendapatkan maserat, lalu dievaporasi dan diuapkan menggunakan waterbath hingga diperoleh ekstrak kental (Depkes RI, 2009).

\section{Pemeriksaan Karakteristik Spesifik}

\section{Uji Makroskopik}

Uji makroskopik bertujuan untuk menentukan ciri khas simplisia dengan pengamatan secara langsung berdasarkan bentuk simplisia dan ciricirinya.

\section{Uji Mikroskopik}

Pemeriksaan mikroskopik pada serbuk simplisia bawang dayak. Diletakkan pada objek glass yang telah ditetesi larutan kloralhidrat serbuk simplisia, ditutup dengan kaca penutup, lalu diamati dibawah mikroskop (Mierza, 2017). 


\section{Penetapan Kadar Air}

Ditimbang 2 gram serbuk simplisia, dimasukkan ke dalam oven selama 30 menit dengan suhu $105^{\circ} \mathrm{C}$. Setelah 30 menit dimasukkan ke dalam desikator selama kurang lebih 15 menit, ditimbang hingga bobot yang didapat konstan.

$$
\begin{aligned}
& \text { Kadar air }=\frac{W 1-W 2}{W 3} \times 100 \% \\
& \mathrm{~W} 1=\text { Berat cawan }+ \text { Sampel sebelum } \\
& \text { dikeringkan }(\mathrm{g}) \\
& \mathrm{W} 2=\text { Berat cawan }+ \text { Sampel sesudah } \\
& \text { dikeringkan } \\
& \text { W3 = Berat awal sampel }
\end{aligned}
$$$$
\text { (Andarwulan, 2011). }
$$

\section{Penetapan Kadar Abu}

Digerus sebanyak 2 gram serbuk simplisia, ditimbang, dimasukkan ke dalam kurs porselen yang terlebih dahulu telah dipijar dan ditara, kemudian diratakan. Kurs dipijarkan sampai bobot tetap. Kadar abu dihitung terhadap bahan yang telah dikeringkan di udara (Depkes RI, 1995).

\section{Penetapan Kadar Abu tidak Larut} Asam

Dididihkan abu yang diperoleh pada penetapan kadar abu dengan 25 $\mathrm{ml}$ asam klorida encer selama 5 menit, bagian yang tidak larut asam dikumpulkan, disaring dengan kertas saring bebas abu, dicuci dengan air panas. Residu dan kertas saring dipijar sampai bobot tetap. Kadar abu yang tidak larut dalam asam dihitung terhadap bahan yang telah dikeringkan di udara (Depkes RI, 1995)

\section{Penetapan Kadar Sari Larut Air}

Timbang saksama lebih kurang $5 \mathrm{~g}$ serbuk (4/18) yang telah dikeringkan di udara. Masukkan ke dalam labu bersumbat, tambahkan $100 \mathrm{~mL}$ air jenuh kloroform, kocok berkali-kali selama 6 jam pertama, biarkan selama 18 jam. Saring, uapkan $20 \mathrm{~mL}$ filtrat hingga kering dalam cawan dangkal beralas datar yang telah dipanaskan $105^{\circ}$ dan ditara, panaskan sisa pada suhu $105^{\circ}$ hingga bobot tetap. Hitung kadar dalam \% sari larut air.(Depkes RI, 2009)

\section{Penetapan kadar Sari Larut Etanol}

Timbang saksama lebih kurang 5 g serbuk (4/18) yang telah dikeringkan di udara. Masukkan ke dalam labu bersumbat, tambahkan $100 \mathrm{~mL}$ etanol $\mathrm{P}$, kocok berkali-kali selama 6 jam pertama, biarkan selama 18 jam. Saring cepat untuk menghindarkan penguapan etanol,uapkan $20 \mathrm{~mL}$ filtrat hingga 
kering dalamcawan dangkal beralas datar yang telah dipanaskan $105^{\circ} \mathrm{C}$ dan ditara, panaskan sisa pada suhu $105^{\circ} \mathrm{C}$ hingga bobot tetap. Hitung kadar dalam \% sari larut etanol.(Depkes RI, 2009)

\section{Skrining Fitokimia}

Skrining fitokimia merupakan analisis awal yang dilakukan untuk mengetahui jenis metabolit sekunder pada akar kuning. Beberapa pengujian yang dilakukan adalah alkaloid, flavonoid, saponin, tanin dan steroid / triterpenoid(Depkes R1, 199).

\section{HASIL DAN PEMBAHASAN}

\section{Identifikasi Tumbuhan}

Hasil determinasi menunjukkan bahwa sampel yang digunakan adalah tumbuhan, Fibraurea tinctoria, dari famili Menispermaceae.

\section{Hasil Karakterisasi Serbuk akar} kuning Uji Makroskopik

Hasil uji Makroskopik tumbuhan akar kuning merupakan jenis Liana dengan panjang mencapai 10-20 m, Batang: bulat, kulit batang coklat keabu-abuan, kasar, diameter antara 2-7 cm, memiliki daun majemuk, panjang sekitar $15 \mathrm{~cm}$, berbentuk bulat lonjong dan warna serbuk simplisia kuning cerah.

\section{Uji Mikroskopik}

Hasil pengamatan (gambar 1) menunjukkan ciri khas dari jenis akar kuning berupa fragmen trakea dan sel batu. Kedua fragmen penanda ini dapat digunakan untuk membedakan simplisia akar kuning yang beredar di pasar dan mencegah dari pemalsuan simplisia.

Hasil Pengujian Parameter Spesifik Hasil karakterisasi pemeriksaan parameter spesifik dapat dilihat pada tabel 1 .

Menurut Depkes RI (2000), parameter spesifik mencakup identitas ekstrak, organoleptik ekstrak, senyawa terlarut dalam air dan etanol dan kandungan kimia ekstrak.

Penetapan kadar sari larut air untuk mengetahui kadar senyawa kimia bersifat polar yang terkandung di dalam simplisia, yang hasilnya diperoleh $8,05 \%$ pada simplisia. 
Tabel 1. Hasil pengujian parameter spesifik

\begin{tabular}{lc}
\hline Parameter & Hasil \\
\hline Identitas: & ekstrak etanol \\
Nama ekstrak & batang \\
Bagian tanaman & Coklat gelap \\
\hline Organoleptik: & kekuningan \\
Warna & Non aromatis \\
& Pahit \\
Bau & Ekstrak kental \\
Rasa & \\
Bentuk & $8,05 \%$ \\
\hline Kadar senyawa larut dalam: & $6,69 \%$ \\
Air & \\
Etanol & \\
\hline
\end{tabular}

Kadar sari larut dalam etanol dilakukan untuk mengetahui kadar senyawa larut dalam etanol, baik senyawa polar maupun non polar diperoleh hasil $6,69 \%$ pada simplisia. Kandungan sari larut dalam air lebih tinggi dari pada kadar sari larut etanol, ini berarti senyawa kimia yang larut dalam air lebih banyak dibandingkan larut etanol dikarenakan senyawa yang terlarut pada etanol adalah senyawa polar maupun senyawa non polar, bila penarikan senyawa polar dan non polar sama banyaknya tertarik pada etanol, maka akan menyebabkan titik jenuh. Menurut Saifudin et al. (2011), penetapan kadar senyawa terlarut ini bertujuan untuk memperkirakan kandungan senyawa aktif yang bersifat polar (larut air) dan senyawa aktif yang bersifat semi polar atau non polar (larut dalam etanol).

\section{Hasil Skrining Fitokimia}

\section{Serbuk akar kuning}

Hasil pemeriksaan skrining fitokimia dapat dilihat pada Tabel 2 .

Serbuk simplisia akar kuning yang ditambahkan dengan pereaksi Mayer, Bouchardat dan Dragendrof menunjukan adanya endapan yang sesuai dengan literatur, berarti serbuk simplisia dan ekstrak etanol mengandung alkaloid.

Sedangkan pada pengujian senyawa flavonoid terbentuknya warna kuning pada lapisan amil alkohol diduga karena reduksi oleh gas hidrogen setelah penambahan asam klorida pekat dan serbuk magnesium menjadi aglikonnya (Robinson,1995). Selanjutnya senyawa hasil reduksi akan 
membentuk senyawa komplek warna kuning (Wardana et al, 2016). dengan magnesium membentuk

Tabel 2. Kandungan kimia ekstrak

\begin{tabular}{|c|c|c|c|}
\hline \multirow{2}{*}{ No } & \multirow{2}{*}{$\begin{array}{c}\text { Golongan } \\
\text { senyawa }\end{array}$} & \multicolumn{2}{|c|}{ Hasil } \\
\hline & & Pereaksi & Fibraurea tinctoria \\
\hline \multirow{3}{*}{1} & \multirow{3}{*}{ Alkaloid } & - Mayer & (+) Endapan putih \\
\hline & & - Bouchardat & $(+)$ Endapan coklat $(+)$ \\
\hline & & - Dragendrof & Endapan merah coklat \\
\hline \multirow[t]{2}{*}{2} & \multirow{2}{*}{ Flavonoid } & Serbuk $\mathrm{Mg}+\mathrm{HCl}$ & (+) Warna merah \\
\hline & & pekat + amil & pada lapisan amil \\
\hline 3 & Tanin & $\begin{array}{l}\text { Air hingga bening } \\
\quad+\mathrm{FeCl}_{3} 1 \%-\end{array}$ & $(-)$ \\
\hline \multirow[t]{4}{*}{4} & \multirow[t]{4}{*}{ Saponin } & Air panas, dikocok & \multirow{4}{*}{$\begin{array}{l}\text { (+) Terbentuk busa } \\
\text { permanen } 1,5 \mathrm{~cm}\end{array}$} \\
\hline & & $+\mathrm{HCl} 2 \mathrm{~N}+$ & \\
\hline & & n-heksan, diuapkan & \\
\hline & & + As. Asetat anhidrat & \\
\hline 5 & Steroid/triterpenoid & $+\mathrm{H}_{2} \mathrm{SO}_{4}-$ & $(-)$ \\
\hline
\end{tabular}

Senyawa flavonoid juga pertumbuhan jamur (Khotimah K, berpotensi sebagai antioksidan 2016).

karena strukturnya mengandung Pemeriksaan terpenoid serbuk gugus hidroksil yang dapat simplisia dan ekstrak etanol mendonorkan atom hidrogennya membentuk warna hijau kebiruan kepada radikal bebas (Supomo pada saat penambahan asam asetat et al, 2017). anhidrat dan asam sulfat pekat. Skrining saponin yang Menurut Harborne (1996), jika dilakukan pada serbuk simplisia dan mengandung senyawa terpenoid ekstrak etanol menghasilkan busa apabila ditambahkan asam asetat yang permanen dan tidak hilang anhidrat dan asam sulfat pekat akan dengan penambahan $\mathrm{HCl} 2 \mathrm{~N}$., terbentuk warna hijau atau hijau penambahan $\mathrm{HCl} 2 \mathrm{~N}$ mengakibatkan kebiruan. Berdasarkan hasil skrining kestabilan busa semakin lama. fitokimia yang dilakukan diketahui Saponin dapat berkhasiat bahwa akar kuning mengandung menurunkan tegangan permukaan senyawa alkaloid, flavonoid, saponin sehingga dapat menghambat dan terpenoid. Hasil tersebut sesuai 
dengan penelitian $\mathrm{L}$ Zalizar, dkk (2019) bahwa akar kuning mengandung metabolit sekunder alkaloid, Flavonoid dan saponin.

\section{Hasil Pengujian Parameter Non} Spesifik

Penentuan kadar abu bertujuan untuk menentukan karakteristik sisa kadar abu non organik setelah pengabuan. Kadar abu ekstrak akar kuning dalam penelitian ini adalah $8,17 \%$ dan kadar abu larut asam 0,47\%. Hal ini menunjukkan bahwa sisa bahan anorganik dalam simplisia akar kuning sebesar 8,17 \%. Kadar abu hendaknya mempunyai nilai kecil karena parameter ini menunjukkan adanya cemaran logam berat yang tahan pada suhu tinggi (Isnawati dan Arifin, 2006). Berdasarkan Kepmenkes RI Nomor 261/MENKES/SK/IV/2009 bahwa kadar abu ekstrak tidak boleh lebih dari 10,2 \% (Depkes RI., 2009).

Tabel 3. Hasil pengujian parameter

\begin{tabular}{lc}
\multicolumn{2}{c}{ non spesifik } \\
\hline \multicolumn{1}{c}{ Parameter } & Hasil \\
\cline { 2 - 3 } & Fibraurea tinctoria \\
\hline Kadar abu total & $8,17 \%$ \\
Kadar abu larut & $0,47 \%$ \\
asam & \\
Kadar air & $7,3 \%$
\end{tabular}

\section{KESIMPULAN}

Hasil karakterisasi serbuk simplisia akar kuning secara makroskopik, merupakan Liana dengan panjang mencapai 10-20 m, dengan batang bulat, kulit batang coklat keabu-abuan, kasar, diameter antara 2-7 cm dan warna serbuk kuning cerah. Mikroskopik serbuk simplisia ditemukan fragmen sel batu dan fragmen trakea. Karakterisasi serbuk simplisia, kadar air 7,3\%, kadar sari larut etanol 6,69\%, kadar sari larut air 8,05\%, kadar abu $8,17 \%$, kadar abu tidak larut asam 0,47\%. Hasil identifikasi golongan senyawa kimia, positif mengandung alkaloid, flavonoid dan saponin.

\section{UCAPAN TERIMA KASIH}

Tim Peneliti Mengucapkan Banyak terima Kasih kepada Direktorat Riset dan Pengabdian Masyarakat Kementerian Riset dan Teknologi/Badan Riset dan Inovasi Nasional atas pendanaan pada penelitian ini. Pada Skim PKPT (Penelitian Kerjasama Antar Perguruan Tinggi dengan nomor kontrak/ SPPK: 


\section{DAFTAR PUSTAKA}

Andarwulan, N, Kusnadar F dan Herawati D, 2011. Analisa Pangan. Jakarta: PT. Dian Rakyat.

Departemen Kesehatan RI. 1995. Farmakope Indonesia Edisi IV. Direktorat Jenderal Pengawasan Obat dan Makanan. Jakarta.

Departemen Kesehatan RI. 1995. Materia Medika Indonesia. Edisi VI. Jakarta: Depkes RI. Hal: 120,317,321,324,325,340

Departemen Kesehatan RI. 2000. Parameter Standar Umum Ekstrak Tumbuhan Obat. Jakarta: Depkes RI. Hal: 1, 5, 10-11, 14, 17, 31-32

Departemen Kesehatan RI. 2008. Farmakope Herbal Indonesia. Jakarta: Depkes RI. Hal: 164165,174

Departemen Kesehartan RI. 2009, Keputusan Mentri Kesehatan Republik Indonesia Nomor: 261/MENKES/SK/IV/2009 tentang Farmakope Herbal Indonesia, Menteri Kesehatan Republik Indonesia, Jakarta

Harborne, J. B. 1996. Metode Fitokimia. Penerbit ITB: Bandung. Hal: 151, 234

Isnawati, A., dan Arifin K.M., 2006, "Karakterisasi Daun Kembang Sungsang (Gloria superba L) dari aspek Fitokimia" Media Litbang Kesehatan, 16(4), 8-14

Khusnul, K. $2016 . \quad$ "Skrining Fitokimia dan Identifikasi Metabolit Sekunder Senyawa Karpain Pada Ekstrak Metanol Daun (Carica pubescens Lenne \& K.Koch) dengan LC/MS".
Skripsi. Malang: Universitas Islam Negeri Malang. Hal: 3941.

Mierza V,Suryanto D,Nasution MP,2011.Skrining Fitokimia Dan Uji Efek Anti bakteri Ekstrak Etanol Umbi Bawang Dayak Sabrang (Eleutherine palmifolia Merr.). Skripsi. Medan: Universitas Sumatera Utara.

Robinson, T. 1995. Kandungan Senyawa Organik Tumbuhan Tinggi. Bandung: Institut Teknologi Bandung. Hal: 47-53

Supomo, Syamsul E.S,, Manurung, N. 2017. "Uji Aktivitas Antioksidan Ekstrak Etanol Umbi Bawang Rambut (Allium chinense G.Don) Dengan Penagkal Radikal DPPH (1,1-Difenil-2Pikrilhidrazil)". Jurnal Ilmiah Sehat Bebaya. Vol. (2)1: 165166.

Saifudin, A., Rahayu \& Teruna. 2011. Standardisasi Obat Alam. Graha Ilmu. Yogyakarta.

Turjaman, Maman. 2015. Obatobatan Alternatif Tanaman Hutan. RPPI 6. Badan Litbang dan Inovasi Kementerian Lingkungan Hidup dan Kehutanan.

Wongbutdee, J. 2009. Physiological effect of berberine. Review article. Thai Pharmaceutical and Health Science Journal, 4(1).

Wardana A.P, Tukiran. 2016. "Skrining Fitokimia dan Aktivitas Antioksidan Ekstrak Kloroform Tumbuhan Gowok Syzygium polycephalum)". Prosiding 
Seminar Nasional Kimia. Vol. (1):4-5

Zalizar, Rahayu, Sujona and Nor A.Y. 2019. Potency of Fibraurea tinctora Lour. extract as anti-bacterial agents towards pathogenic bacteria. The 2nd International Conference on Natural Resources and Life Sciences (NRLS). IOP Conf. Series: Earth Environ. Sci. 293 012026. 